\title{
Strates
}

STRATES Matériaux pour la recherche en sciences sociales

2| 1987

Mélanges

\section{Présent/passé : La colonisation japonaise à Taïwan}

\section{Catherine Paix et Michèle Petit}

\section{(2) OpenEdition}

\section{Journals}

\section{Édition électronique}

URL : http://journals.openedition.org/strates/332

DOI : $10.4000 /$ strates.332

ISSN : 1777-5442

Éditeur

Laboratoire Ladyss

Édition imprimée

Date de publication : 1 janvier 1987

ISSN : 0768-8067

\section{Référence électronique}

Catherine Paix et Michèle Petit, «Présent/passé : La colonisation japonaise à Taïwan », Strates [En ligne], 2 | 1987, mis en ligne le 08 décembre 2004, consulté le 08 septembre 2020. URL : http:// journals.openedition.org/strates/332; DOI : https://doi.org/10.4000/strates.332

Ce document a été généré automatiquement le 8 septembre 2020

Tous droits réservés 


\section{Présent/passé : La colonisation japonaise à Taïwan}

Catherine Paix et Michèle Petit 